\title{
Using fuzzy time series with and without markov chain: to forecast of edible bird nest exported from Indonesia
}

\author{
Osfar Sjofjan ${ }^{1 *}$ and Danung Nur Adli ${ }^{1,2}$ \\ ${ }^{1}$ Faculty of Animal Science, Universitas Brawijaya, Jl. Veteran, Malang 65145, Indonesia \\ ${ }^{2}$ Animal Feed and Nutrition Modelling Research Group (AFENUE), Department of Animal Nutrition \\ and Feed Technology, Faculty of Animal Science, IPB University, Bogor 16680, Indonesia
}

\begin{abstract}
Edible bird nest (EBN) were traditional medicine consumed by the Tiongkok. This study compared two-algorithm method. Fuzzy time series and Markov chain as forecast method the number of bird nest exported from Indonesia. The secondary data between 2012 and 2018 were from Bureau Central Statistic (BPS). The scope using in this study were bird nest between 2012 until 2018, with a unit of volume kilograms (Kg). Used secondary export data, collected from BPS of Indonesia. Data were analysed using Fuzzy Time Series with and without Markov Chain using R Studio. The result showed that Fuzzy Time Series with and without Markov Chain method performs better in the forecasting ability in short-term period prediction and the values of Mean Absolute Percentage Error (MAPE) and Mean Square Error (MSE) tends to be smaller than the Fuzzy Time Series without Markov Chain. It can be concluded the number of exported can be used Fuzzy time series.
\end{abstract}

\section{Introduction}

One of them is influenced by the composition and nutrition of the feed ingredients used in the feed mixture so that it can accelerate of poultry [1-3]. Feed material is any food that can be eaten, preferred, partially or completely digested, absorbable and beneficial for livestock $[4,5]$. Edible bird nest (EBN) were traditional medicine consumed by the Tiongkok. Edible bird nest were the most expensive animal products, which products by salivation of swiftlets (Aerodramus fuciphagus). Swiflets in Indonesia called wallet and edible bird nest were sarang wallet. The swiftlets were speeded between entire rest of the world. The exported of this product were increase during recently five years. During five years a rural economic were helps to maintenance balancing of rural economical farmers in urban area [1]. There are inconsistently data such as Indonesia, there is a lot of method that can be used in the livestock data. For example are meta-analysis that uses to coin a single experiment by used various models instance a dataset $[6,7]$. But, later we forget to conduct the estimated or rearrange plant of the idea of the research. One of the method is calling fuzzy time series. Time series

\footnotetext{
*Corresponding author: osfar@ub.ac.id
} 
forecasting is the process of analyzing time series data using statistics and modelling to make predictions and inform strategic decision-making $[8,9]$.

In accordance to increase a number of imported number there are predict and mathematical models to use it. Russian experts named A. A. Markov in 1906 first developed the Markov Chain (Markov Chain) [10]. Conceptually the Markov chain can be illustrated by assuming $\{X n, \mathrm{n}=0,1,2 \ldots\}$ as a finite stochastic forecasting value [11].

\section{Materials and methods}

There is a largely lacking data of the livestock sector that can be used to be exported. We try to reach data more stable, until we selected this sector as the data. The scope using in this study were bird nest between 2012 until 2018, with a unit of volume kilograms (kg). Used secondary export data, were collected from BPS of Indonesia [3]. Data were analysed using Fuzzy Time Series with and without Markov Chain. The steps were divided into 4 steps there were: determine the set of universes, create fuzzy sets, perform fuzzification, create FLR, create FLRG and defuzzify using software. Furthermore, library "AnalyzeTS" "Fuzzynumbers" and "fuzzysTs" are installed. Moreover, our data scientist are using ggplot2 library to conduct also the map origin that exported to origin contries.

Table 1. Edible bird nest of swiflet Export Data 2012- 2018

\begin{tabular}{|c|c|c|}
\hline Time & Period & Netweight (tonnes) \\
\hline 1 & 2012 & 405.321 \\
\hline 2 & 2013 & 536.787 \\
\hline 3 & 2014 & 636.104 \\
\hline 4 & 2015 & 761.216 \\
\hline 5 & 2016 & 992.161 \\
\hline 6 & 2017 & 1286.648 \\
\hline 7 & 2018 & 1291.987 \\
\hline
\end{tabular}

Source: [3], various years from 2012 to 2018 , after fitted data to probes $0.25 ; 0,75 ; 1.00$

\subsection{Time series analysis}

The actually main function time series analysis were to forecast or predictions of the data. The assumption first derivative as exploration of time. In this experiment were not determine random component but stationary data. In order to forecast future values of exported data [1]. The main objective in analysing time series is to understand, interpret and evaluate changes in the phenomena in the hope of more correctly anticipating the course of future events.

\subsection{Fuzzy set and forecasting}

The fuzzy sets theory can be defined as a mathematical formalization that enables us to eliminate indefiniteness and deal with incomplete, inaccurate information of both qualitative and quantitative data [3]. The fuzzy set were classical mathematical method introduction from [12]. 


\subsection{Fuzzy time series (FTS)}

Fuzzy Time Series (FTS) is a forecasting data method that uses the concept of fuzzy set as the basis of calculations. The forecasting system with this method works by returning patterns from actual data and then used to project future data. The process also does not require a learning system from a complex system, as is the case with genetic algorithms and neural networks [13]. Furthermore, Fuzzy Time Series (FTS) has terms that are published, namely Fuzzy Logic Relations (FLR) and Fuzzy Logic Relations Group (FLRG). Fuzzy Logic Relations (FLR) is a fuzzy logic that has a relationship between the series of associations that have been set in the previous data and continued. Then FLRG is only the same as FLR, but only what is determined is the group making from FLR which is the same as the weighted group.

The algorithm as following step from Devore, et al. [14]

$$
A i=f A i(u k) / u k+f A i(u k) / u k+\ldots+f A i(u k) / u k
$$

Step 1. Finding discourse and the intervals. as:

$$
U=[D \min -D 1, D \max +D 2]
$$

Notes: D1 and D2 are the positive number that determines the effective long interval is the average based Fuzzy Time Series model [14].

Step 2. Separated between the intervals. Partition universal discourse U into several equal intervals. Let the universal discourse $U$ be partitioned into $n$ equal intervals; the difference between two successive intervals can be defined as $\ell$ as follows:

$$
\ell=[(D \max +D 2)-(\operatorname{Dmin}-D 1)] / n
$$

Step 3. Classify the fuzzy sets.

Step 4. Fuzzy the data. Fuzzy the actual data.

$$
\begin{gathered}
\ell=[(\operatorname{Dmax}+D 2)-(D \min -D 1)] / n \\
F(t)=(m 1+m 2+m j) / n
\end{gathered}
$$

\section{Results and discussion}

\subsection{Comparison of fuzzy time series and markov chain}

In the beginning the author try to reach data of livestock sector that present exported product but later there is inconsistently data that provided on exported on livestock sector. Generally, fuzzy time series methods are based on three stages [13-15]. These are fuzzification, determination of fuzzy relation, and defuzzification [8]. In the literature [9-11], the fuzzy time series methods are improved by employing various artificial intelligence techniques in these three stages. The genetic algorithms, particle swarm optimization, and fuzzy c-means methods are used in the fuzzification stage. Feed forward neural networks are used determining fuzzy relation and defuzzification stage. Many time series in actual life to defined uncertain observations. This kind of the time series is called fuzzy time series. 
Table 2. The forecasted values of Indonesia bird nest swift let

\begin{tabular}{|c|c|c|c|c|c|c|c|}
\hline Time & Year & $\begin{array}{c}\text { Actual } \\
\text { data }\end{array}$ & $\begin{array}{c}\text { Fuzzy } \\
\text { Data }\end{array}$ & Time & Year & $\begin{array}{c}\text { Actual } \\
\text { data }\end{array}$ & $\begin{array}{c}\text { Fuzzy } \\
\text { Data }\end{array}$ \\
\hline 1 & 2012 & 405.321 & A1 & 16 & 2012 & 405.321 & A2 \\
\hline 2 & 2013 & 536.787 & A1 & 17 & 2013 & 536.787 & A3 \\
\hline 5 & 2016 & 636.104 & A1 & 20 & 2016 & 636.104 & A4 \\
\hline 7 & 2018 & 761.216 & A2 & 30 & 2018 & 761.216 & A1 \\
\hline
\end{tabular}

Forecasting using Fuzzy Time Series (FTS) is done to get the appropriate comparison model. The difference between Fuzzy Time Series-Markov Chain (FTS-MC) and FTS is the forecasting step. Forecast calculations using FTS use equations (Rule1), (Rule2), and (Rule3). For example, for forecasting in 1990 the data seen is the previous year's data, namely 1989 where the state transitioned from $A 1$ to $A 1$, the forecasting calculation uses equation (7) because of Fuzzy. Our fuzzy time series found that the actual data from 2012 until 2018 following forecasted value were at near to the actual value which is range 2016-2018 were at $429,919-1429,919$. While, the adjusted forecasting value started from 2012 until 2018 are $308.730 ; 848.41,0,0,0,0,4.83$ respectively.

Table 3. Forecasting of Indonesian birdnest Export

\begin{tabular}{|c|c|c|c|c|}
\hline Year & Actual data & $\begin{array}{c}\text { Forecasted } \\
\text { Value }\end{array}$ & $\begin{array}{c}\text { Adjusted } \\
\text { Value }\end{array}$ & $\begin{array}{c}\text { Adjusted } \\
\text { Forecasting value }\end{array}$ \\
\hline 2012 & 405.321 & 395.321 & -384.89 .41 & 308.730 \\
\hline 2013 & 536.787 & 636.787 & 0 & 848.41 \\
\hline 2014 & 636.104 & 845.214 & 0 & 0 \\
\hline 2015 & 761.216 & 341.216 & 0 & 0 \\
\hline 2016 & 992.161 & 1092.161 & $429,919.83$ & 0 \\
\hline 2017 & 1286.648 & 1106.648 & $1429,919.83$ & 0 \\
\hline 2018 & 1291.987 & 1491.987 & $429,919.83$ & 4.83 \\
\hline
\end{tabular}

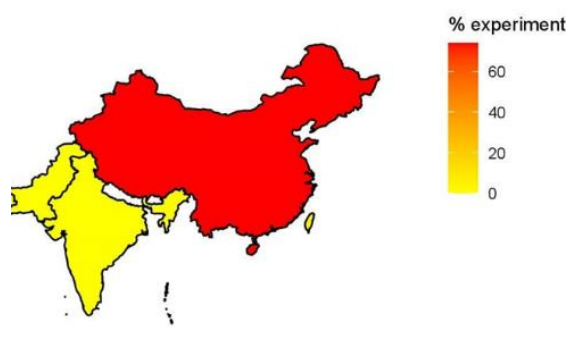

Fig. 1. Actual and estimated of the edible bird nest exported from Indonesia on countries origin target. (Figures are belong to author itself). 


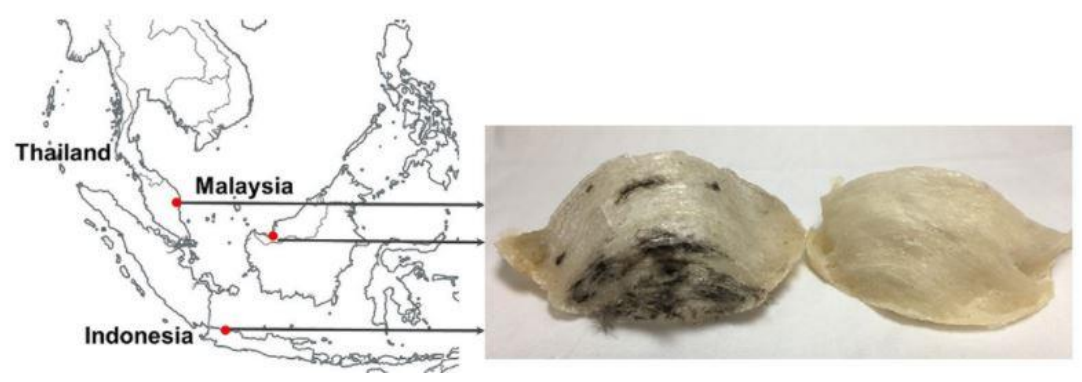

Fig. 2. The location of edible bird nest (EBN) based on the countries origin adapted from [16].

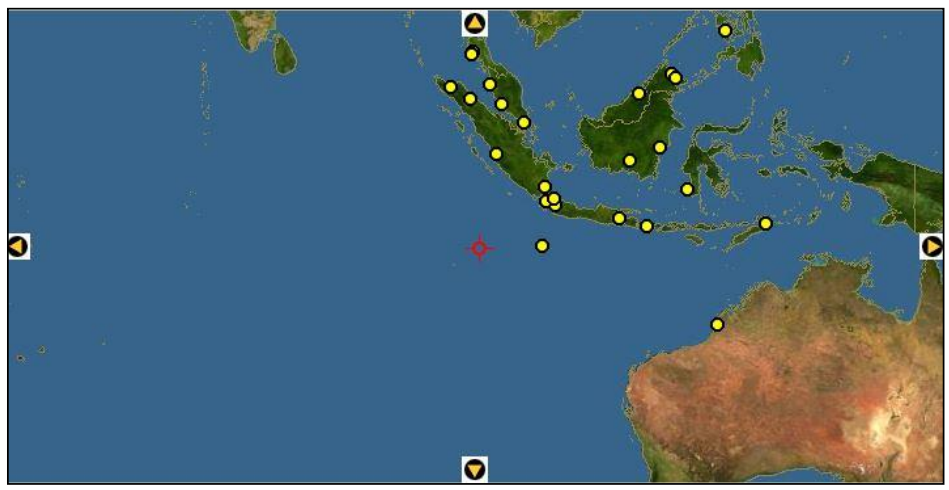

Fig. 3. Pin point view of Aerodramus fuciphagus, the dataset are Indonesia countries.

Map center: NAD83 Lat-long $10.5^{\circ} \mathrm{S} 99^{\circ} \mathrm{E}$; UTM 47 500000E 8839306N Resolution 0.125 degrees/pixel, Target $10.2^{\circ} \mathrm{S} 99^{\circ} \mathrm{E}$. Source [17]

\subsection{Challenges future after using fuzzy time series on edible bird nest}

Fuzzy Markov Chain in regard to the proposed method is $2.1 \%$ and $1.26 \%$. That the forecasting error of Mean Absolute Percentage Error (MAPE) and Mean Square Error (MSE) Fuzzy Time Series proposed method is $1.0 \%$ and 0,5 which is better than that of the other methods. Moreover, that according to figure 1. Our edible nest are mostly exported to china mainland, Taiwan, Hong Kong, Japan, and Korea. Following by new emerging market that started from 20-40\% exported are in the Middle East. Thus, research in the edible nest are largely unknown. Our hypothesis the total value of the edible bird nest (EBN) are only reached tens millions of total production. Whether, this are only informal sector of Indonesia's economy that is difficult to estimate. But, this sector are underestimated from this country. The unregulated industry are raised through year of year (yoy) that Indonesia swiftlet farmers could producing more than just nest. The bird nest must be utilisation in accordance to fulfil requirement. Another, obstacle are since 2003 the virus H5N1 or later called avian flu are most trouble for responsibilities 146 dead. Later, it was coined as global fears of a pandemic. The number of toll in Indonesia are reached highest in the world (Fig 2 ). The problem in the future are caused by diseased $[16,20]$. Water pump must be acquired maintenance to inhibit mosquitoes [17-19].

\section{Conclusion}

Because edible bird nest (EBN) are mostly potential of exported end product from livestock sector since the china mainland are using for herbs it should be optimise of it potential both 
government, private sector, or even scientist. There is a lot fuzzy time series can be used as this model such as Markov chain, arima, Chen, Singh, hybrid, grey, or even novelty of this fuzzy time series. We suggest for doing this research in the future. Last, It can be concluded the number of exported can be used Fuzzy time series.

We would to say thanks to central bureau statistics to provide an open access data for exported edible bird nest, later we say thanks to whose providing library R studio from BPPT Cran.

\section{References}

1. O. Sjofjan, D. N. Adli, M. H. Natsir, Y. F. Nuningtyas, I. Bastomi, F. R. Amalia, J. Indones. Trop. Anim. Agric. 46 (2021)

2. O. Sjofjan, D. N. Adli, M.H. Natsir, Y. F. Nuningtyas, T. S. Wardani, I. Sholichatunnisa, S. N. Ulpah, O. Firmansyah, Jurnal Ilmu Ternak dan Veteriner, 26 (2021)

3. Badan Pusat Statistik, Jakarta. Indonesia (2018)

4. O. Sjofjan, M. H. Natsir, D. N. Adli, D. D. Adelina, L. M. Triana, IOP Conf. Ser. Earth Environ. Sci. 465 (2020)

5. D. N. Adli, O. Sjofjan, M. H. Natsir, Y. F. Nuningtyas, N. Sholikah, A. C. Marbun, Livestock Res Rural Dev. 32 (2020)

6. O. Sjofjan, D. N. Adli, M. M. Sholikin, A. Jayanegara, A. Irawan, J. Anim. Feed Sci. 30 (2021)

7. O. Sjofjan, D.N. Adli, IOP Conf. Ser. Earth Environ. Sci, 478 (2020)

8. J. A. Rice, Int. J. Appl. Math, (2007)

9. C. H. Wang, Tourism Management, 25 (2004)

10. X. Zeng, L. Shu, J. Jiang, International Journal of Applied Mathematics, 46 (2016)

11. O. Sjofjan, D. N. Adli, R. P. Harahap, A. Jayanegara, D. T. Utama, A. P. Seruni, F1000Research, 10 (2021)

12. E. Eğrioğlu, Adv. Fuzzy Syst. (2012)

13. S. C. Albright, C. J. Zappe, W. L. Winston, Data Analysis and Decision Making (2011)

14. J. L. Devore, K. N. Berk, Modern Mathematical Statistics with Application (2007)

15. H. Guney, M. A. Bakir, C. H. Aladag, International Journal of Fuzzy Systems, 20 (2018)

16. E. K. Shim, S. Y. Lee, Spectroscopy Europe, 29 (2017)

17. L. Discover, Australia: Thomson Brooks/Cole. (2021)

18. D.N. Adli, Y. Chi, J. W. Lee, O. Sjofjan, nt. j. adv. eng. res. sci. 4 (2019)

19. D. N. Adli, Livestock Res Rural Dev, 33 (2021a)

20. D. N. Adli, Livestock Res Rural Dev, 33 (2021b) 